\title{
CAN SYSTEMS THEORY PREDICT THE EVOLUTION OF SECESSIONISM IN CATALONIA WITH RESPECT TO THE KINGDOM OF SPAIN?
}

\author{
Author(s) / Auteur(s) : \\ Member of IASCYS (International Academy for Systems and Cybernetic Sciences); President of Honor of SESGE \\ (Sociedad Española de Sistemas Generales); Editor of AVANCES SISTÉMICOS \\ Email: parraluna3495@yahoo.es
}

\begin{abstract}
Résumé :
The tendency toward secession of approximately half of Catalan voters is a complex phenomenon that has been worsening for about 15 years, first because of the desire of the Catalan secessionists to have a new Statute of Autonomy incompatible with the rest of the autonomies, and second, for failure of the Central State to implement the promise of President Zapatero in 2011 to accept the Statute to be drafted by the Catalans. From that moment and also thanks to the political inaction of President Rajoy, the Catalan problem has only escalated until it announces a Unilateral Declaration of Independence destined to die before being born due to the illegalities that allowed it. In this situation, the Systemic Model that is presented predicts a certain evolution towards the decrease of the secessionist drive.
\end{abstract}

Keywords / Mots-clés :

secession; perspectivism; causal model, weighting of variables, trend calculation

\section{AUTHOR'S NOTICE}

I try to be a rigorous scientist. That is why I must start by saying that I am against the secession of Catalonia for the following reasons:

1. Because in general I prefer the union and collaboration of people, animals or things, to their separation and self-absorption.

2. Because it is a matter of rich versus poor or less rich.

3. Because secession reduces the social dimension (responsibility) of the person.

Having declared this, my study will have selected and organized some variables so that they produce the result that I am pursuing.

Therefore, the reader must replace the variables and their organization in a different model to see if it gives a different result..

\section{INTRODUCCIÓN}

It is convenient to start by remembering that the terms "separatism" and "secessionism" are not exactly synonymous. You can be "independent" without having been separated or "seccesioned", which happens with a multitude of objects, animals, entities and people. Spain is an independent country, as is France, but as current nation-states never (which the author knows) have suffered a process of separation from another country. One can be independent as, eg, the author of these lines, and not proceed from the separation of another human being. For someone who is independent does not need to do anything, only continue to be. But to be separated you have to exercise the act of separation, you have to carry out an effort, a struggle, cause a break, ... all of which will surely involve some costs .. In the dictionary of the Royal Academy of the Language (1), among the terms that are dedicated to "independentism" do not cite "secessionism" as an analogous or close term, and vice versa, when the latter is defined they do not refer to the first. And the same thing happens in the ESPASA (2) dictionary of synonyms and antonyms: when about 50 synonyms of independence and derivatives are 
cited, not a single one makes reference to secessionism, and the same happens with the latter, where of the twenty synonyms mentioned none of They are referring to the independence movement. It seems more appropriate, then, to call the phenomenon of the so-called "Catalan independence movement", purely and simply what it is: "secessionism", "separation", "cutting", "distancing" ... all of which imply concrete positive acts that contrast with the quietism of being or remaining independent.

With this clarification, the secessionist attempts of Catalonia are not new in history (3). Already in 1641 the first attempt was made that became so effective that Catalonia separated from the Spain of Philip IV to belong to the kingdom of France of Louis XIII during the 12 years that go from 1641 to 1653, happening that after this experience Catalonia was integrated into Spain because the policy of Louis XIII, with Richelieu as prime minister was more centralist than that of Philip IV with the CountDuke of Olivares de Valido.

And nothing so decisive happened during the next two centuries until the Second Spanish Republic when the second attempt took place that led Macia in 1931 to be the first President of the Catalan Republic during the brief period of 1933 when he died.

A third attempt took place shortly after when in 1934 Companys became the second President of the "independent" Catalonia, for whose cause he was shot to death in 1940 by the Franco dictatorial regime.

And the fourth attempt is represented by Puigdement in 2017 and whose main characteristic is to have occurred precisely when less historical possibilities had to end successfully, due to the series of objective and inevitable factors that intervene against such claim as will be seen in the model that follows. And highlighting among them, the belonging to the European Union, which, as a unionist project of countries, could not be more shocking, contradictory and impossible to be accepted, by a "unilateral" declaration of independence, clearly illegal and obsolete for the rest of the 28 European countries. What it is hard to believe is like in the series of circumstances that our model points out, how the secessionist leaders assume such a tremendous and risky adventure, that has ended with their president escaped and wanted by the Spanish Justice and the rest of his team, also escaped or in Spanish prisons. Attempts that are repeating the story up to four times and all of them characterized by having broad international repercussions with the same result.

The predictive model that follows presents five blocks of variables (circumstances and facts) that explain how a systemic approach could predict the next electoral results in Catalonia. I will use a simplified schema for this, but it may be useful to illuminate the effects of both the recent secessionist attempt and the events and circumstances that have occurred so far.( ISM)

We start from the following causal scheme (Figure 1) where the arrows with sign " + " indicate a favorable influence on the independence of Catalonia with respect to the Spanish kingdom, while the arrows "without sign" indicate a negative influence or contrary to said secession.

The first block is formed by the three circumstances (peripheral region, different language, and higher income per capita) where, mainly the latter, is determining a generalized secessionist behavior (sign +) where they occur (Basque Country, Flanders, Padania, Bavaria, Santa Cruz in Bolivia, etc.). In the case of Catalonia, it has created a structural expectation that oscillates around 45-48\% of secessionists (called "independentistas") versus 52-55\% of unionists (called "constitutionalists"). 


\section{PREDICTIVE CAUSAL MODEL ON CATALAN SECESSIONISM}

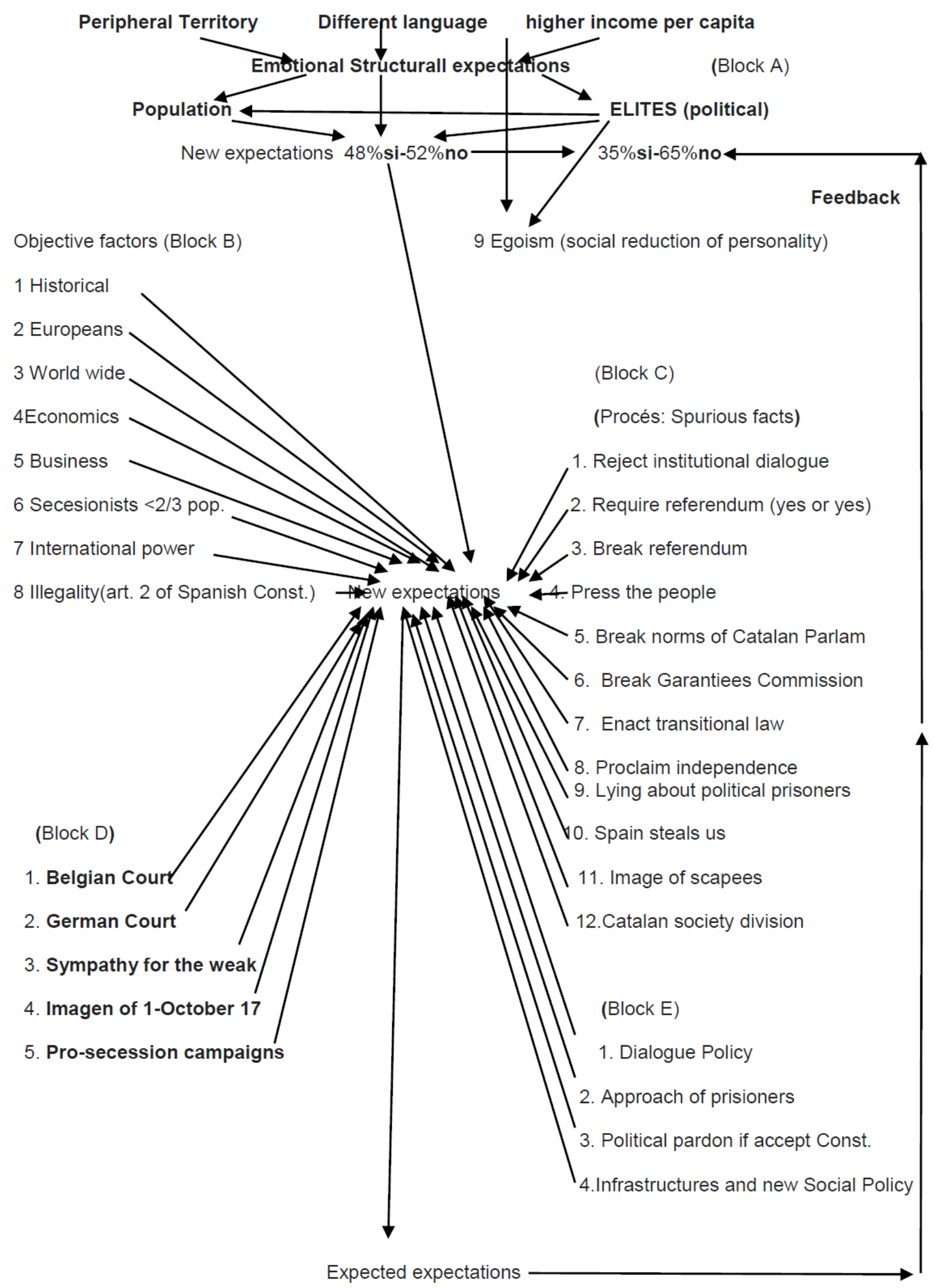


Resulting, then, the differential of "income per capita" with respect to the rest of Spain the great explanatory variable of the secessionist attitude, however also presents its corresponding by product derived from the "capped" desire not to share wealth or join with other "poorer" "(or" less rich "), responding in the background to that human natural tendency impregnated with the so-called" selfish gene "as presented by R. Dawkins (4). And we say "byproduct" from the secessionist perspective because that selfishness does not stop having a double meaning: On the one hand it plays a positive role ("+" sign) for mobilizing all those who in the concrete Catalan case maintain the "Spain steals us" ", what it is a general separatist tendency of all the economically more developed regions. But on the other hand, this initial positive influence would be counteracted in a second negative moment in fig. 1 (arrow that goes from the superior "income per capita" to the "secessionist desire", now without a positive sign) since that typical reaction of the rich man that has an important psychosocial effect, namely little social prestige, together with a reduction of the social dimension (field of socio-ethical commitmen)t of the secessionist. In this sense and from a "social" perspective, the secessionist person dwarfs, surrounds himself with a breath or smaller social circle, which inevitably happens when they even declare themselves "citizens of the world". And in the case at hand, it is inevitable that a Catalan secessionist is less a citizen of the world than a Catalan unionist, since he does not exclude anyone from his social circle.

But to revert to the central theme of the article, a series of objective factors immediately come into play that are going to halt, and even make almost impossible, the secession of Catalonia (eg, the "Europe" effect, other important countries of the world, the economy; business world, the global integration trend, the least diplomatic influence, the lack of majority support of the Catalan population, and above all, the ILLEGALITY factor that plays a fundamental role against the possible secession of Catalonia compared to the rest of Spain given the requirements of the Spanish Constitution (5) whose article 2 says:

The Constitution is based on the indissoluble unity of the Spanish nation, common and indivisible homeland of all Spaniards, and recognizes and guarantees the right to autonomy of the nationalities and regions that integrate it and the solidarity among them."

This single variable, put in any model that tries to predict the possibility of this secession, would be enough to foresee a very low probability of occurrence. Keep in mind that this would have to begin by amending the Spanish Constitution where the following process would need to be followed: a) The 2/3 conformity of both houses (Congress and Senate); b) Hold new elections and resubmit the text to be accepted by $2 / 3$ of the two chambers; and c) Hold a referendum for ratification. A chimerical goal given the widespread acceptance of the Spanish population to continue as a unified historical country.

Adding still greater improbability to secession is another third block of variables (Block C) produced during the so-called "Proces" through a series of statements that are objectively "spurious" such as: that the Spanish State does not want to dialogue (it is not to the central State to whom it is appropriate to initiate the dialogue, but to the one that wishes to change the situation, as Ibarretxe did in 2005); imposing a "yes or yes" referendum on the state; to adopt a referendum against what is established by the Constitutional Court; Encouraging people to participate in such illegality; abusing the legality of the Catalan parliament itself by imposing laws with an insufficient majority; ignore the Guarantee Committee and the jurists of the Catalan Chamber; the holding of the banned referendum, thus provoking the intervention of the police (the secessionists would be solely responsible for the injuries produced); constantly proclaim that there are "political prisoners" ( they are only politicians who are in prison for breaking laws ); that Spain is not a "State of Law"; that Catalonia was always a nation like the current nation-states; that "Spain steals" the Catalans ..... and some more.

On the contrary, they could also play a certain role, this time in favor of secession, the following five variables that make up Block "D" as the pronouncement of the Belgian court not extraditing Puigdement; the same or similar procedure of a German court; the sympathy that people usually feel in any confrontation between the "small" (Catalonia) and the "big" (Spain): the international image of Spain undoubtedly damaged by the police charges of October 1, 1017, or the continuous campaigns of secessionists (yellow tie and others) that try to keep the secessionist claim alive. 
Finally play a 'negative role from the secessionist perspective (Block E) the foreseeable changes that will take place the Spanish government since the replacement of Rajoy by Sanchez, this is: a) the new socialist government's dialogue attitude probably aimed at earning certain sympathies of that Catalan population that has doubts on the convenience of secession: b) the approach of the politicians who are prisoners, thus fulfilling the most advanced norms on location of prisoners in populations near their homes; c) the possible pardon in favor of the secessionist politicians (prisoners or escaped) that could be carried out by the new socialist government if the Constitution is respected; and d) a new policy for the construction of infrastructures and social improvements that would favor the majority of the Catalan population, marking certain differences with the policy of the previous PP. Four measures, however delicate, because they would have to move between a disguised (and even critical) satisfaction of the Catalan secessionists always asking for more, and the criticism of the parties of the Spanish right ("PP" and "Ciudadanos") accusing them of surrender to the forces that supported in the motion of censure against the previous president Rajoy.

But the very structure of the causal model, even without considering the relative "weights" of each of the variables, speaks in principle on its own. With only three positive initial signs for secession, although the five variables of Block D are added, they allow for a certain logical result to be advanced, which would even change the initial expectations from $45 \%$ / 55no to those of $35 \%$ / $65 \%$, even less favorable for the expectations of secessionists.

Thus, an approximate quantification of the change in terms of "probabilities" ( ) can be made based only on the number of intervening variables and without taking into account their relative weight. Therefore, and as a merely tentative calculation, of $3 / 3=1$ of the first block (success of the independence movement sure to be the three "balls" of the same color), it is passed to the second block with $3 / 9=0.3$ as probability given the national and international objective factors that would oppose secessionism; to continue with the aggravation of the "procés" by the errors committed in Block C, thus determining a result of: $3 /(9+13)=0.14$; although adding the five positive variables contributed by Block " $\mathrm{D}$ " we would have $3+5 / 9+13$ ) $=0.36$ significantly increasing the "probability" of success, but finally moving to include the effects of Block "E" and its four negative variables, we would have 3 $+5 / 9+13+4=0.31$ hypothesis that, definitely, would point to a rather low "probability" that the Catalan secession will triumph in some way. These are some initial calculations considering that all the factors have the same value.

But not all the variables have the same specific "weight", so this conclusion would be too simplistic. The problem is now in determining that "relative weight" in a common interval 0-100, from questions to a sample of "experts" large enough to be able to obtain a significant average. Consisting of the second problem added, in determining this sample that will always be complicated. What follows next, then, is a mere attempt to weight variables using only three experts, although carefully selected for their intellectual formation, knowledge of the problem and maximum political neutrality or at least focused and compensatory.

The Excel box that follows presents the three evaluations, their average and the first calculations that allow, based always to divide the points in favor of secession $(\mathrm{Y})$ by the points in favor of the union $(\mathrm{X})$ and where the general formula of probability (Pr) without weighting remains: $\operatorname{Pr}=\Sigma \mathrm{Y} / \Sigma \mathrm{X}$.

Table 1: Relative weight of the variables in the predictive model 


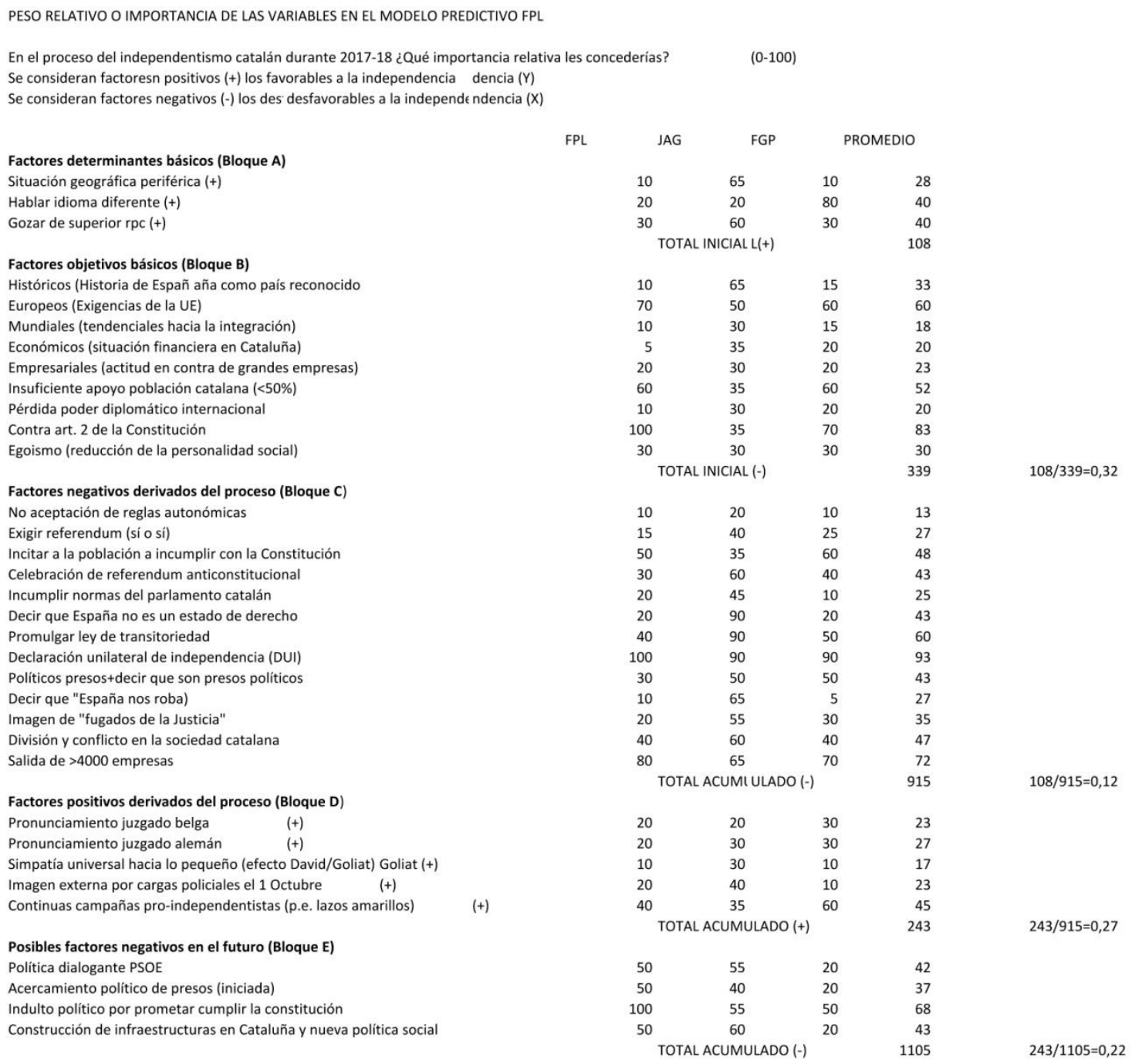

So the model allows to separate the four phases through which it would happen:

Phase 1:

Taking into account only the three initial variables (+) of Block A and the negative 9 of Block B, the expression:

$$
\operatorname{Pr}=\Sigma \mathrm{Yp} / \Sigma \mathrm{Xp}=\mathbf{0 . 3 2}
$$

it would mark that secession would have only a $32 \%$ chance of getting ahead, or of 0.3 , in terms of probabilities.

Phase 2:

The numerator does not change when considering only the three initial positive variables, but in the denominator the 13 variables of Block $\mathrm{C}$ are now integrated, so we have:

$$
\operatorname{Pr}=\sum \text { Yp } / \Sigma X p=\mathbf{0 . 1 2}
$$


decreasing the percentage of success to 12 , logical thing due to the series of factors considered "spurious" and or negative for secession.

Phase 3:

During this phase, the five facts of Block D are produced, which would favor the secessionist aspirations in principle, thus adding the components of Yp. Thus:

$$
822
$$

$$
\operatorname{Pr}=\Sigma \mathrm{Yp} / \Sigma \mathrm{Yp}=\mathbf{0 . 2 7}
$$

$1 \quad 1$

Thus achieving overcome the secessionist possibilities up to $27 \%$.

Phase 4:

This phase would be started but not finished. But if the four facts of Block E were produced, which will probably happen if negotiations continue as the only possible way out of the problem, then we would have:

$$
8 \quad 26
$$

$$
\operatorname{Pr}=\Sigma Y p / \Sigma X p=\mathbf{0 . 2 2}
$$

With what, the model would come to predict that the secessionist process would end with such a low

\begin{tabular}{|c|c|c|c|c|}
\hline & & & & \\
\hline & & & & \\
\hline & & & & \\
\hline & & & & \\
\hline & & & & \\
\hline \multicolumn{5}{|l|}{0,5} \\
\hline 0,48 & $\mathrm{X}_{2}$ & & & \\
\hline & - & & & \\
\hline & 0,32 & 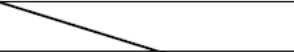 & 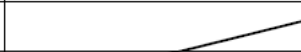 & \\
\hline & & & 1 & 0,22 \\
\hline & & 0,12 & 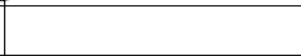 & \\
\hline
\end{tabular}
probability of occurring as the 0.22 , that is, reducing even the most favorable situation for the secessionists that reached 0.27 over "1" as shown in figure 2 .

$$
\begin{array}{llcccl}
\text { Block A } & \text { Block B } & \text { Block C } & \text { Block D } & \text { Block E } \\
\text { 2012-2016 } & \text { Sep/Oct,2017 } & \text { Pr.semest.2018 } & \text { Seg. Semest.2018 } & 2019
\end{array}
$$

1

Fig. 2: The dynamic effects of the "procés" in terms of "probability" 0-1

The dynamic hypothesis suggested by the model is the following: Starting from the existence of $48 \%$ of secessionists before starting the "procés", the tendency that originates the same, mainly due to the fact that the factors that objectively oppose it are discovered from various areas, starting with the existence of a Constitution that strictly prohibits it, is that it will lose strength in the coming months and years due to the confluence of, at least, the following four factors: a) the joint action of the 34 variables included in the model: b) the new policy that can be expected from the Central governments, scalded by the lack of dialogue with the Generalitat; c) the new policy that can be expected on the part of the Generalitat equally scaled by the results of its unilateral policy during the "procés"; and d) the understandable tiredness of Catalan citizenship when they realize that secession is unfeasible, that large companies do not accept any "procés", and that it is necessary for social and citizen relations to return to a more normal state and less hurt or committed to secessionism. 


\section{ADVANCE CONCLUSION FROM AN OPTIMISTIC PERSPECTIVE (OVERCOMING THE CONFLICT)}

The problem can also be seen from the decidedly optimistic perspective, and in this case it is convenient to reinterpret what can happen after the central government applies the last four measures expected from the new tone in the Central Government-Generalitat relations.

Because if the secessionists began accepting the existing rules of the game, but without losing sight of the possibility of modifying them, the following sequence of events could happen: 1) The secessionists agree to comply with and enforce the Constitution: 2) the Central Government promotes the pardon both those in prison and those who remain fleeing from justice, while improving social services and increasing the construction of infrastructures in Catalonia; 3) Institutional autonomy returns to normal functioning; and 4) Certain changes in the Constitution can then be proposed, including the Monarchy / Republic disjunctive, provided all the necessary constitutional requirements are met (qualified majorities in Congress and Senate and referendum at the level of the Spanish state).

The key is that the secessionists accept to respect the rules of the game (in football terms, "do not score goals with your hand") and commit to respect and enforce the Constitution, even if only they want to change it with the urgency and radicality that allows them their capacity to convince and the rules of the current Constitution.

A first conclusion is, then, the following: unless we have forgotten to include in the model any very significant variable in the process, or the weighting of them has been very unfortunate, there do not seem to be other possibilities of conflict resolution that are not a flexible negotiation based on the Spanish Constitution and willing to reach a lasting agreement that avoids or dilutes over time the current confrontation in Catalan society. After the regrettable consequences suffered by both parties (unconstitutional referendum, 1-O incidents, unilateral declaration of independence, escape of political leaders, imprisonment of others, departure of companies, etc.) it is to be hoped that future governments of Spain as the new leaders of the Catalan Autonomy, realize that only the collaboration and negotiation together with the rest of the Autonomies have, in the integrated Europe of today, a future political journey

Does it all mean that only $22 \%$ of Catalan voters will opt for secession in the next consultations?. No way. It is one thing to predict the possibilities of secession (22\%) and another to predict the behavior of Catalan voters in an electoral consultation who have no knowledge of the variables that play in the final prediction, so the percentage of secessionists is assumed it would remain, in principle, around its current $48 \%$.

What is possible, is to risk the integrated action of two conjectures: first, that the model $(\operatorname{Pr}=22 \%)$, thanks to the inherent force of the described events, ends up penetrating and influencing a large mass of the Catalan secessionist population; and second, that this same mass of secessionist population (Se $=48 \%$ ), based as it is known in feelings rather than in reason, remains insensitive to the reasons of the model.

Then as a product of this integrated action for a few more years, when the four policies of Block $E$ are being implemented, a certain final prediction of the model could be enunciated as a result of some kind of average between both trends, that is:

Prediction $=(\operatorname{Pr}+\mathrm{Se}) / 2=(22+48) / 2=35 \%$

The model would register its own "feedback" to end up lowering the initial proportion of secessionist voters that would most likely be between 30 and $40 \%$.

Does this mean that the model will hit the 35th / 65th ratio, and that only $35 \%$ of the votes would be for the secessionists in the next elections? The logic of the system proposes this, but multiple lastminute circumstances can substantially change the prediction. 


\section{ADVANCE CONCLUSION FROM A PESSIMISTIC PERSPECTIVE (CONTINUATION OF CONFLICT)}

So far, the model and its action, has involved adopting a somewhat optimistic perspective. But other perspectives can be contemplated: because from a pessimistic perspective, regardless of the rationality of the model, another more basic prediction very incardinated in the stubbornness of the attitudes based on the following three principles can be anticipated:

1) The central government, in accordance with current regulations, does not feel obliged to take initiatives in this regard. Any claim in this sense would correspond to the Catalans and therefore the only option is to wait for the secessionist leaders to propose and defend their claims before the Spanish Parliament, just as Ibarretxe did in 2005. It has been the policy of President Rajoy.

2) The problem then arises from the inability of the secessionists to demonstrate before the Spanish parliament the only convincing argument: that the requested secession would be good for the rest of Spain and for Catalonia and in all the dimensions that affect the population (health, income per capita, liberties, justice, employment, ecology, international power, etc.).

3) Something practically impossible to prove. But the radicalized secessionists, as actors already submerged in the typical political tragi-comedy, prefer to continue acting as "victims" and without getting off the stage to contemplate "their" particular stalls full of people applauding, attitude that is something narcissistic but human and understandable. And

4) As users of a brain already normally dominated by the LIMBIC (emotional) part, at the expense of the NEOCORTEX (rational) part, they would not have the operative capacity to recognize and accept the irrationality and consequences of illegal attitudes. And they will argue that, whatever happens, the independence of Catalonia is inevitable as it is the common feeling of radical secessionists (eg, Arzallus prophesied solemnly in 1994 that in 1998 Euskadi would be independent).

In principle, then, and from a pessimistic perspective, the rest of Spain-Catalonia relationship, would remain as an unsolvable problem "per secula soculorum".

\section{FINAL CONCLUSION}

The secession of Catalonia from the rest of Spain seems highly unlikely. Starting from this premise, two basic outputs would present the problem: the collaborative and the conflictive. The first one adopting a new coexistence improving certain aspects of the Spanish autonomic organization in function of its diversity (eg, through an appropriate "Federalist" figure): the second festering the problem in a way as absurd as damaging to the interests of Catalonia, Spain and Europe, for not extending it to the other countries that are more involved.

Given these two perspectives, the conclusion is therefore the following: trying to overcome any previous political condition, whether "by" or "against", and unless we have forgotten to include in the model any very significant variable in the process, or the weighting of these have been very unfortunate, there do not seem to be other possibilities for resolving the conflict that are not a flexible negotiation based on the current Constitution and eager to reach a lasting agreement that avoids or dilutes over time the current confrontation in the Catalan society itself. After the regrettable consequences suffered by both parties (unconstitutional referendum, 1-October incidents, unilateral declaration of independence, escape of political leaders, imprisonment of others, departure of companies, position of the Spanish justice before the Belgian and German courts, sympathy towards Catalonia for being the weak party and police charges, visibility of the secessionist campaigns, disobedience and lack of respect for the Spanish State, ...) it is to be hoped that both, the new leaders of Catalan Autonomy as well as the future governments of Spain, use or jump once from the limbic brain (emotions) to the neocortex brain (rationality) and realize that only joint collaboration and negotiation with the central state and the rest of the autonomous regions, have in the Integrated Europe of today's future political journey. O as the Observer (24/9/2017) put is: "No dreams, please. Secession, in a democratic Spain inside a democratic Europe, has to be pursued calmly and honestly. 
You can understand the drumbeats of separation, especially in a region where the actual presence of Madrid governance on the ground in country towns and villages is already vestigial. You can also, as with Brexit, feel the tumult of economic disaster 10 years ago still making waves. But civil unrest and wild words promise only more disaster. It is time for both sides to pause and ponder the damage. It's time to pull back.

\section{RÉFÉRENCES}

APSA (American Political Science Association), "La ciencia política y su incapacidad de predicción", Jun 26, 2012. (www)

Bruce Bueno de Mesquita, "Can Game Theory Predict When Iran Will Get the Bomb?., NYT CLIVE THOMPSON, August 12, 2009

Attri R. Et al. "An ISM approach for modelling the enablers in the implementation of total Productive Maintenance (TPM), in International Journal System Assurance Engineering and Management, DOI: 10.1007, (2012)

Boscan Carrasquero, G. "La modelización formal en la ciencia política: usos, posibilidades y limitaciones,", Polit. Gob. vol 17, no. 1 México, Ene. 2010.

Centre d'Estudis d'Opinio (CEO). "Barómetro de Opinión Política de Junio 2017.

Dawkins, Richard, "El gen egoísta": las bases biológicas de nuestra conducta", Salvat Ciencia, 2002.

Garson, G. David, "Social Science Computer Simulation: Its History, Design and Future" in Social Science Computer Review, vol, 12,pp.55-82 (1994)

Garson G. David, "Computerized Simulation in the Social Sciences: A Survey and Evaluation", Simulation and Gaming, en SAGE Journals on line (20 Agosto 2008)

Morton, Rebecca, "Methods and Models: A Guide to the Empirical Analysis of Formal MODELS in Political Science", N.Y. Cambridge Univ. Press., 2005.

Observer (The). "The Observer view on Catalan independence" (Observer editorial), 26/9/2018

Rajesh Attri, Nikhil Dev., and Vivek Sharma, "Interpretive Structural Modelling (ISM) approach: An Overview", Research Journal of Management Sciences, Vol.2(23), 3-8 February 2013

Ravi V. And Shankar R., Analysis of interactions among the barriers of reverse logistics", Technological Forecasting and Social Change, 72, 1011-1029, 2005

Singh et al. "Modelling of critical sucesss factors for implementation of AMTYs, in Journal of Modelling in Management, 2(3), 232-250, (2007)

BolanosR., et al. "Using interpretive structural modelling in strategic decision making groups", Management Decision, 43 (6), 877-895 (2005)

Stevens, J. "Political Scientists are Lousy Forecasters", New York Times (June 24, 2012) 